\title{
PERENCANAAN PROGRAM INTERPRETASI LINGKUNGAN DALAM PENGELOLAAN WISATA DI MAROON MANGROVE EDU PARK SEMARANG
}

\author{
Planning of Environmental Interpretation Program in Tourism Management \\ at Maroon Mangrove Edu Park Semarang
}

\section{Louis Allen Sipayung, Frida Purwanti*) dan Sahala Hutabarat}

\author{
Program Studi Manajemen Sumberdaya Perairan Departemen Sumberdaya Akuatik \\ Fakultas Perikanan dan Ilmu Kelautan Universitas Diponegoro \\ J1. Prof. Soedarto, SH, Tembalang, Semarang, Jawa Tengah - 50275, Telp/Fax. +6224 7474698 \\ Email : allen.sipayung@gmail.com
}

\begin{abstract}
ABSTRAK
Interpertasi lingkungan dapat berperan penting dalam ekowisata dengan memberikan edukasi kepada pengunjung tentang potensi kawasan, informasi tentang konsekuensi pada setiap tindakan dan mengubah perilaku pengunjung untuk melestarikan lingkungan. Penelitian dilaksanakan pada bulan Februari 2017, dengan tujuan mengkaji profil dan persepsi pengunjung, mengidentifikasi ketersedian media informasi dan menyusun program interpretasi lingkungan. Metode yang digunakan dalam penelitian adalah metode deskriptif. Pengumpulan data dilakukan dengan teknik wawancara menggunakan kuesioner terhadap 50 pengunjung serta Focus Group Discussion (FGD) dengan stakeholder MMEP Semarang. Observasi dilakukan untuk mengidentifikasi ketersediaan media informasi yang ada di MMEP Semarang. Profil pengunjung yang datang ke MMEP Semarang paling banyak dari kelompok anak muda yang berusia antara 15-24 tahun dan berasal dari wilayah Semarang sekitarnya (Kedungsepur). Persepsi pengunjung tentang informasi potensi wisata MMEP Semarang melalui program interpretasi yang ada, menunjukkan bahwa sebagian besar pengunjung (70\%) masih kurang mendapatkan edukasi mengenai potensi wisata. Ketersediaan media informasi yang ada di MMEP Semarang terdiri dari papan informasi potensi alam, papan petunjuk arah, papan sejarah penanaman mangrove, papan informasi karcis, papan sejarah awal lokasi wisata dan papan larangan wilayah Lanumad. Program interpretasi lingkungan sesuai road map pengembangan wisata tahun 2015-2020 meliputi peyediaaan jasa pemandu wisata yang kompeten dan perbaikan fasilitas interpretasi yang sudah ada.
\end{abstract}

Kata Kunci: Interpretasi Lingkungan; Wisata; Media Informasi; Maroon Mangrove Edu Park

\begin{abstract}
Environmental interpretation play an important role in ecotourism by educating visitors about the potency areas, providing information on the consequences of each action and stimulating visitor behavior to preserve the environment. The study was conducted in February 2017, with the aims to assess visitor profiles and perceptions, to identify the availability of information media and to develop environmental interpretation programs. The method used in this research is descriptive method. The data were collected by interviewing to 50 visitors using questionnaires and Focus Gorup Discussion (FGD) with stakeholders at MMEP Semarang. Observations were conducted to identify the availability of information media in MMEP Semarang. Profile of visitors who come to MMEP Semarang are mostly a group of young people with aged between 15-24 years and came from Semarang. The visitor perception about information of tourism potential at MMEP Semarang from the existing interpretation program, has shown that most of the visitors (70\%) get less education about tourism potential. Availability of information media available in MMEP Semarang consists of natural potential information board, direction board, mangrove planting history board, ticket board information, early history board of tourist sites and ban board of Lanumad area. The environmental interpretation program would be develop according to the road map of tourism development 2015-2020 are providing competent tour guides and upgrading the existing interpretation facilities.
\end{abstract}

Keywords: Enviromental Interpretation, Tourism, Information Media Maroon Mangrove Edupark

*) Penulis Penanggungjawab

${ }^{\circ}$ Copyright by Management of Aquatic Resources (MAQUARES) 


\section{PENDAHULUAN}

Ekosistem hutan mangrove merupakan ekosistem utama dalam mendukung kehidupan di wilayah pesisir dan sangat khas karena terdapat di daerah estuarin yang secara teratur digenangi air laut dan dipengaruhi oleh pasang surut dengan kondisi tanah lumpur berpasir yang dipengaruhi oleh kadar garam (salinitas). Vegetasi yang terdapat dalam ekosistem mangrove didominasi oleh Avicennia sp, Sonneratia sp, Rhizophora sp dan Bruguiera sp.

Salah satu upaya pemanfaatan sumberdaya pesisir khususnya ekosistem mangrove adalah dengan mengembangkan kegiatan pariwisata melalui konsep ekowisata. Dalam konteks ini wisata yang dilakukan memiliki bagian yang tidak terpisahkan dengan upaya-upaya konservasi, pengembangan program-program interpretasi lingkungan dan pemberdayaan ekonomi lokal. Secara sederhana, konsep ekowisata menghubungkan antara perjalanan wisata alam yang memiliki visi dan misi konservasi dan kecintaan lingkungan. Hal ini dapat terjadi karena keuntungan finansial yang didapat dari biaya perjalanan wisata digunakan juga untuk kebutuhan konservasi alam serta perbaikan kesejahteraan penduduk lokal.

Ekowisata merupakan bentuk pariwisata yang relatif baru dimana hampir setiap negara di seluruh dunia ikut terlibat di dalamnya. Salah satu lokasi ekowisata adalah Maroon Mangrove Edu Park (MMEP) yang berada diantara Pantai Maron dan run away Bandara Ahmad Yani Semarang yang telah dijaga dan dilestarikan. Kawasan MMEP Semarang memiliki fungsi pokok sebagai perlindungan ancaman abrasi, pengawetan keanekaragaman hayati, peningkatan kesadaran masyarakat dalam menjaga wilayah pesisir, serta pemanfaatan melalui kegiatan ekowisata secara lestari sehingga dapat meningkatkan perekonomian masyarakat nelayan yang ikut berpartisipasi dalam kegiatan ekowisata. Kawasan ini memiliki keunikan kondisi alam, keanekaragaman hayati, letak kawasan yang strategis serta memiliki jalur tracking yang terbuat dari bambu sepanjang 70 meter. Kawasan MMEP dikembangkan dalam pengawasan PT. Phapros, Tbk (RNI Group) yang merupakan perusahaan yang bergerak di bidang farmasi dan Yayasan Ikamat sebagai konsultan pengembang ekowisata di MMEP. Pengelola langsung kawasan MMEP adalah kelompok tani Mekar Tani Lindung (Metal) yang merupakan petani tambak dan nelayan di wilayah tersebut.

Permasalahan perencanaan pengembangan ekowisata di MMEP Semarang saat ini adalah minimnya media informasi seperti leaflet yang memiliki pesan edukasi. Informasi dan program paket wisata terkait dengan keunikan dan kekhasan serta potensi wisata yang ada di MMEP Semarang juga masih belum ditemukan. Ketersediaan papan identifikasi jenis, fungsi dan manfaat mangrove yang berada di kawasan belum ditemui.

Ketersedian guide untuk menunjang program interpretasi wisata tidak ada, selain itu, akses jalan menuju daerah objek wisata hanya melalui akses pintu utama bandara Ahmad Yani Semarang dan belum dikelola dengan baik. Keterbatasan petunjuk arah ini menyebabkan kawasan wisata MMEP Semarang belum dikenal dan diketahui wisatawan yang ingin berkunjung. Kenyataan tersebut merupakan peluang bagi pengelola untuk memperkenalkan keunikan dan kekhasan, keanekaragaman hayati serta memberikan peningkatan pelayanan yang maksimal kepada pengunjung sekaligus meningkatkan pengetahuan dan kesadaran dalam menjaga kelestarian kawasan. Salah satu upaya yang dapat dilakukan untuk mendukung kegiatan ekowisata, memberikan pengetahuan dan kesadaran serta meningkatkan pelayanan.

Muntasib (2003) menjelaskan bahwa interpretasi lingkungan memiliki tujuan untuk memberikan pengertian kepada seseorang tentang pengetahuan baru, wawasan baru, antusiasme baru, dan daya tarik baru. Interpretasi lingkungan juga sebagai media komunikatif dalam penyampaian informasi antara sumberdaya dan pengunjung. Interpretasi lingkungan di MMEP Semarang dapat memberikan kesempatan bagi masyarakat sekitar objek wisata untuk ikut serta dalam mendukung kegiatan wisata sehingga secara tidak langsung dapat meningkatkan kesejahteraan dan mewujudkan konservasi mangrove di MMEP Semarang. Untuk itu perlu dikembangkan konsep program interpretasi lingkungan di MMEP Semarang.

Tujuan dari penelitian ini adalah :

1. Mengkaji profil dan persepsi pengunjung di kawasan MMEP Semarang

2. Mengidentifikasi ketersediaan media informasi yang terdapat di kawasan MMEP Semarang

3. Menyusun program interpretasi lingkungan di kawasan MMEP Semarang.

\section{MATERI DAN METODE PENELITIAN}

\section{Materi}

Materi dalam penelitian ini adalah profil dan persepsi pengunjung, ketersediaan media informasi dan program interpretasi lingkungan di Maroon Mangrove Edu Park Semarang.

\section{Metode}

Metode yang digunakan dalam penelitian ini adalah metode deskriptif, dengan tujuan untuk mengetahui gambaran suatu objek pengamatan. Menurut Notoatmodjo (2012), penelitian bersifat deskriptif dengan tujuan utama memberi gambaran atau deskripsi tentang suatu keadaan secara objektif dan digunakan untuk memecahkan atau menjawab permasalahan yang sedang dihadapi.

Responden pengunjung dalam penelitian ini menggunakan teknik accidental sampling. Menurut Sukandarrumidi (2006), accidental sampling atau pengambilan sampel secara kebetulan. Anggota sampel yang tidak direncanakan terlebih dahulu tetapi didapatkan atau dijumpai secara tiba-tiba. Wawancara dengan pengunjung menggunakan panduan kuesioner tertutup (closed questionnaire), yaitu kuesioner yang terdiri dari serangkaian pertanyaan yang sudah disediakan jawabannya sehingga responden tinggal memilih (Arikunto, 2006). Adapun bentuk kuisioner tersebut tersaji dalam Lampiran 1. Pengunjung yang diwawancarai dalam penelitian ini adalah pengunjung yang berusia produktif yaitu usia 15-64 tahun. 
Ketersediaan media informasi yang ada di MMEP Semarang dilakukan dengan menggunakan teknik observasi. Menurut Sugiyono (2009), oberservasi sebagai teknik pengumpulan data mempunyai ciri yang spesifik bila dibandingkan dengan teknik yang lain, yaitu wawancara dan kuesioner. Wawawancara dan kuesioner selalu berkomunikasi dengan orang, maka observasi tidak terbatas pada orang, tetapi juga pada objek-objek alam yang lain. Pendapat Hadi (1986) dalam Sugiyono (2009) mengemukakan bahwa observasi merupakan suatu proses yang kompleks, suatu proses yang tersusun dari berbagai proses biologis dan psikologis diantaranya yang terpenting adalah proses-proses pengamatan dan ingatan.

Kegiatan dalam menentukan perencanaan program interpretasi untuk keberlangsungan wisata di MMEP Semarang adalah dengan melakukan Focus Group Discussion (FGD) atau diskusi kelompok terarah bersama dengan seluruh stakeholder yang ikut ambil bagian seperti PT. Phapros, Tbk, Yayasan Ikamat, Kelompok Tani Metal yang berjumlah 7 -15 orang.

FGD merupakan salah satu metode, teknik dan instrumen pengumpulan data dalam pendekatan kualitatif. Sebagai suatu metode, teknik dan instrumen penelitian, maka tidak perlu dipertentangkan dengan metode lainnya yang ada karena FGD dapat saling melengkapi dengan metode yang lain itu. FGD semakin banyak digunakan sebagai metode, teknik dan instrumen penelitian, termasuk untuk kegiatan pengkajian penjajagan, perencanaan, pelaksanaan, pemantauan dan evaluasi pembangunan. (Indrizal. 2014)

\section{Analisis Data}

1. Analisis terhadap Pengunjung

Hasil wawancara dengan panduan kuesioner pengunjung dianalisis secara deskriptif. Hasil pendeskripsian tersebut dapat memberikan informasi mengenai profil, motivasi, dan persepsi pengunjung MMEP Semarang sekaligus sebagai bahan pertimbangan untuk perencanaan interpretasi lingkungan yang disesuaikan dengan keinginan pengunjung. Analisis nilai penting wisata berdasarkan parameter yang ditanyakan dilakukan dengan mengelompokkan skor persepsi. Skala skoring dibuat dari angka 1-4 untuk menentukan persepsi responden, dimana skor 1 masuk dalam kategori D (sangat buruk), skor 2 masuk dalam kategori C (buruk), skor 3 masuk dalam kategori B (baik) dan skor 4 masuk dalam kategori A (sangat baik). Kemudian dilakukan tabulasi untuk menilai persepsi nilai penting dari parameter yang ditanyakan kepada pengunjung. Analisis pengunjung mengenai nilai penting wisata, dianalisis dengan menggunakan metode presentase dan grafik/tabel (Arisandi et al, 2014).

2. Analisis terhadap Ketersediaan Media Informasi

Hasil observasi terhadap ketersediaan informasi yang ada di MMEP Semarang dianalisis dengan teknik analisis kualitatif yakni menggunakan proses berpikit induktif; artinya, dimulai dari keputusan-keputusan khusus (data yang terkumpul) kemudian diambil kesimpulan secara umum (Notoatmodjo, 2002).

3. Analisis FGD

Hasil pengumpulan data dari FGD dianalisis secara teknik analisis kualitatif. Hasil analisis tersebut akan memberikan suatu kebijakan, rekomendasi dan masukan stakeholder yang akan dikembalikan ke pihak pengelola MMEP Semarang dalam rencana dan arah pengembangan dan pengelolaan wisata.

\section{HASIL DAN PEMBAHASAN}

\section{Deskripsi Lokasi MMEP}

Kawasan ekowisata MMEP merupakan satu dari destinasi wisata yang ada di Kota Semarang yang dibuka dan diresmikan pada tanggal 12 Maret 2016 oleh Walikota Semarang. Kawasan MMEP berada di wilayah Lanumad Ahmad Yani yang merupakan daerah bebas terbatas dibawah pengawasan TNI dan tepat berada di antara run away Bandara Ahmad Yani Semarang dan Pantai Maron.

Sejarah awal terbentuknya kawasan MMEP adalah dari tanggung jawab sosial sebuah perusahaan farmasi bernama PT. Phapros Tbk Semarang melalui CSR-nya melakukan kegiatan rehabilitasi wilayah pesisir khususnya di Semarang dengan cara menjalankan program penanaman mangrove yang difokuskan di wilaya Pantai Maron Semarang. Tujuan pengembangan kawasan MMEP juga sebagai tempat untuk pemberdayaan masyarakat yang secara tidak langsung dapat meningkatkan perekonomian petani tambak melalui kegiatan ekowisata mangrove. PT. Phapros bekerja sama dengan Yayasan IKAMaT (Inspirasi Keluarga Kesemat) yang merupakan sebuah yayasan yang bertujuan untuk menyelenggarakan kegiatan pemberdayaan, pembinaan, dan peningkatan kualitas hidup masyarakat pesisir dalam bidang sosial, kemanusiaan dan penelitian, menjalin kerjasama dengan berbagai instansi pemerintah dan non pemerintah yang bergerak dalam bidang pelestarian ekosistem mangrove dan pemberdayaan masyarakat pesisir. Bentuk kerja sama yang dijalankan adalah membina dan mendampingi kelompok petani tambak disebut METAL (Mekar Tani Lindung) dalam mengelola kawasan MMEP menjadi kawasan ekowisata karena pendapatan petani tambak menurun sebesar 75\% akibat dari reklamasi di pantai Maron pada tahun 2013. Skanavis dan Giannoulis (2010) menyatakan, pelibatan masyarakat dalam pengelolaan atau manajemen wisata secara tidak langsung akan mendapatkan manfaat ekonomi dari kegiatan interpretasi lingkungan. Kelompok METAL akan menikmati hasil dari interpretasi terhadap upaya menjadi interpreter / pemandu wisata melalui pelaksanaan program interpretasi. Selain itu kelompok METAL akan berkontribusi dalam usaha konservasi dan pelestarian sumberdaya alam di MMEP Semarang.

Aksesibilitas menuju kawasan MMEP satu-satunya hanya melalui Pintu Utama Bandara Ahmad Yani Semarang. Akses menuju lokasi tergolong sulit karena kondisi jalan yang belum di aspal. Kondisi jalan terdiri dari tanah dan batu- 
batu kecil sehingga ketika musim hujan, jalanan menuju MMEP sangat berbahaya bagi pengunjung yang sudah terbiasa dengan jalanan aspal. Sarana transportasi umum tidak tersedia menuju kawasan ini dikarenakan kawasan ini adalah kawasan bebas terbatas. Pengunjung hanya bisa datang dengan menggunakan kendaraan pribadi baik motor atau mobil. Sarana dan prasarana yang terdapat di MMEP terdiri dari pintu masuk kawasan, pos tiket masuk kawasan MMEP, pos jaga, toilet, aula pertemuan, musholla, gazebo, gardu pandang, tempat parkir, jalur tracking, dan yang terakhir adalah perahu yang bisa dimanfaatkan pengunjung untuk berkeliling melihat mangrove.

\section{Profil dan Persepsi Pengunjung MMEP Semarang \\ a. Profil Pengunjung}

Pengunjung merupakan suatu unsur dalam kegiatan interpretasi lingkungan yang tidak dapat dipisahakan, oleh karena itu perencanaan interpretasi lingkungan yang direncanakan harus sesuai dengan karakterisitik dan persepsi pengunjung (demand). Hasil wawancara yang dilakukan terhadap 50 pengunjung dapat memperlihatkan profil pengunjung, sumber informasi dan pola kunjungan, motivasi, persepsi pengunjung dan persepsi nilai penting. Tabel 2. Profil Pengunjung MMEP Semarang, Februari 2017

\begin{tabular}{|c|c|c|c|}
\hline No. & Komposisi Pengunjung & Jumlah Responden (orang) & Persentase (\%) \\
\hline \multirow[t]{3}{*}{1} & Jenis Kelamin & & \\
\hline & - Laki-laki & 31 & 62 \\
\hline & - Perempuan & 19 & 38 \\
\hline \multirow[t]{4}{*}{2.} & Umur (tahun) & & \\
\hline & $-15-24$ & 34 & 68 \\
\hline & $-25-35$ & 15 & 30 \\
\hline & $->36$ & 1 & 2 \\
\hline \multirow[t]{6}{*}{3.} & Pendidikan & & \\
\hline & - SMP & 1 & 2 \\
\hline & - SMA & 36 & 72 \\
\hline & - D3 & 6 & 12 \\
\hline & $-\mathrm{S} 1$ & 6 & 12 \\
\hline & $-\mathrm{S} 2$ & 1 & 2 \\
\hline \multirow[t]{6}{*}{4.} & Pekerjaan & & \\
\hline & - Wiraswasta & 6 & 12 \\
\hline & - Buruh & 8 & 16 \\
\hline & - Kuliah & 16 & 32 \\
\hline & - Karyawan & 4 & 8 \\
\hline & - Lainnya & 16 & 32 \\
\hline \multirow[t]{3}{*}{5.} & Asal Pengunjung & & \\
\hline & - Kedungsepur & 28 & 56 \\
\hline & - Luar Kedungsepur & 22 & 44 \\
\hline
\end{tabular}

Berdasarkan tabel diatas, pengunjung yang datang ke MMEP Semarang didominasi oleh kelompok umur 15-24 dengan persentase $68 \%$. Pendidikan terakhir pengunjung kebanyakan lulusan SMA dengan persentase $72 \%$ dan asal pengunjung kebanyakan dari wilayah Kedungsepur (Kendal, Demak, Ungaran, Kota Salatiga, Kota Semarang dan Purwodadi) dengan persentase 56\%. Jarak jangkauan yang paling jauh dari wilayah Kedungsepur adalah Purwodadi dengan jarak 74,1 km dihitung dari pusat wilayah Purwodadi (Gambar 5.) Jarak jangkauan yang paling dekat adalah dari pusat kota Semarang dengan jarak 9,5 km. Berikut adalah grafik jarak jangkauan wilayah Kedungsapur menuju MMEP Semarang.

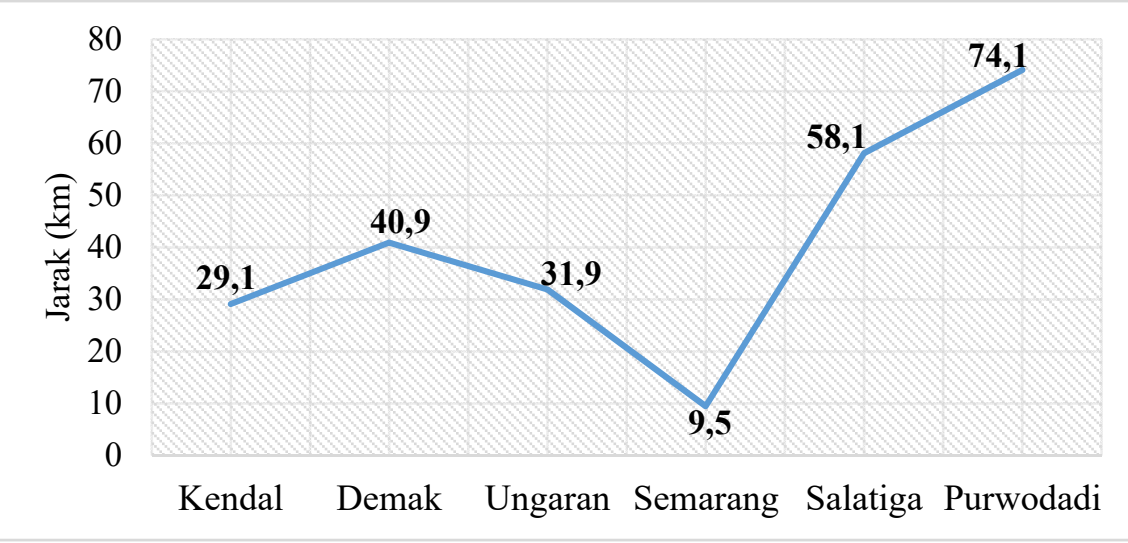

Gambar 5. Grafik Jarak Jangkauan Pengunjung Menuju MMEP Semarang 


\section{b. Sumber Informasi dan Pola Kunjungan}

Berdasarkan hasil wawancara dengan responden pengunjung MMEP Semarang sebanyak 50 respoden, bahwa sebagian besar pengunjung mendapatkan sumber informasi mengenai kawasan MMEP Semarang melalui media sosial yaitu sebesar 54\%. Selain itu, ada sekitar 38\% pengunjung mendapatkan informasi mengenai kawasan MMEP melalui cerita dari teman dan keluarga. Sedangkan sisanya yaitu $8 \%$ pengunjung mendapatkan informasi secara tidak sengaja atau kebetulan melewati jalur menuju pantai Maron. Pengunjung ini tidak menjadikan MMEP sebagai destinasi wisata utamanya karena sejak dari awal pengunjung sebenarnya akan mengunjungi pantai Maron

Berdasarkan hasil wawancara dengan responden pengunjung di MMEP Semarang bahwa sebagian besar pengunjung baru pertama kali melakukan wisata ke MMEP Semarang yaitu sebasar 94\%. Hal ini disebabkan karena kawasan MMEP Semarang masih baru aja diresmikan dan dibuka. Pengunjung yang datang dengan frekuensi $1 \mathrm{s.d} 3 \mathrm{kali}$ berjumlah 6\% dan kebanyakan pengunjung ini berada didaerah kota Semarang dan dekat dengan kawasan MMEP Semarang. Alasan pengunjung melakukan wisata di MMEP dengan frekuensi 1 s.d 3 kali adalah ingin mengajak teman yang belum pernah dan melihat perubahan-perubahan yang terjadi di tempat wisata seperti penambahan sarana dan prasarana.

Responden pengunjung yang di wawancarai lebih banyak melakukan perjalanan wisata ke MMEP Semarang secara kolektif atau rombongan dengan jumlah sebesar 34\%. Jumlah kolektif dan rombongan bervariasi mulai dari 5-10 orang. Pengunjung yang melakukan perjalanan wisata ke MMEP Semarang dengan pasangan berjumlah 26\%, dengan teman berjumlah $24 \%$, dengan keluarga berjumlah $14 \%$ dan sendiri berjumlah $2 \%$. Pengunjung yang melakukan perjalanan dengan teman berjumlah 2-3 orang sedangkan dengan keluarga berjumlah 4-6 orang.

\section{c. Motivasi Kunjungan}

Motivasi pengunjung dalam melakukan wisata akan menjadi informasi yang sangat penting dalam rencana program interpretasi lingkungan. Menurut Athman dan Manroe (2004), bahwa motivasi akan memberikan dampak positif bagi pengunjung dengan meningkatkan rasa keingintahuan yang tinggi terhadap tempat yang dikunjunginya. Sebanyak 36\% pengunjung ingin melakukan rekreasi di MMEP Semarang dan waktu yang dibutuhkan berkisar antara 1-3 jam. Pengunjung ini biasanya adalah pengunjung yang rutin melakukan perjalanan wisata, sedangkan 32\% pengunjung ingin melihat mangrove dan waktu yang dibutuhkan berkisar 1-3 jam. Pengunjung yang ingin melihat mangrove mengindikasikan bahwa pengunjung tersebut memiliki rasa keingintahuan terhadap mangrove.

Peran dan manfaat interpretasi lingkungan wisata di MMEP sangat penting dalam hal ini. Sebanyak 16\% pengunjung mengunjungi kawasan MMEP untuk fotografi dan pengunjung ini kebanyakan menghabiskan waktunya hingga lebih dari 3 jam. Alasan mereka karena ingin mengambil gambar di momen-momen yang tepat. Sisanya $16 \%$ pengunjung datang ke kawasan MMEP untuk kegiatan pendidikan, menanam mangrove, survey tempat-tempat wisata dan lain sebagainya. Pengunjung ini biasanya menghabiskan waktu kurang dari 1 jam khususnya pengunjung yang hanya melakukan survey tempat wisata.

\section{d. Persepsi Pengunjung}

Menurut Rahmat (2005), persepsi adalah pengalaman tentang objek, peristiwa atau hubungan-hubungan yang diperoleh dengan menyimpulkan informasi dan menafsirkan pesan. Selanjutnya Sombowidjojo (1999) mendefinisikan persepsi sebagai pengamatan yang merupakan kombinasi dari penglihatan, penciuman, pendengaran, serta pengalaman masa lalu. Setiap individu menafsirkan sesuatu objek secara berbeda tergantung dari sudut pandang pribadi masingmasing. Hal ini berimplikasi pada bervariasinya persepsi seorang terhadap objek yang sama.

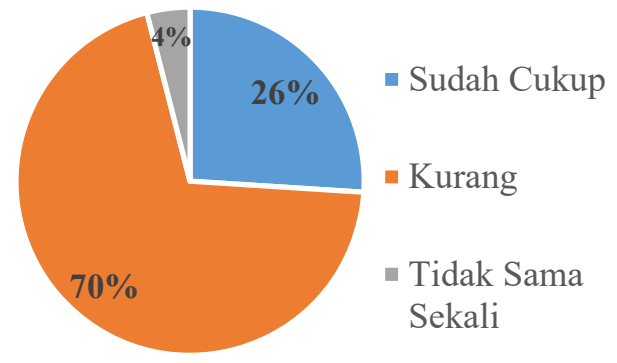

Gambar 10. Diagram tentang Informasi Potensi Wisata di MMEP Semarang

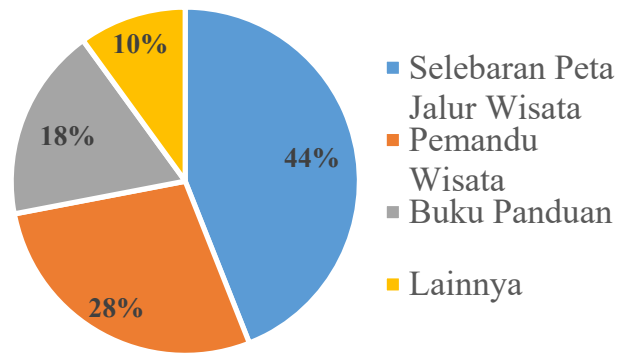

Gambar 11. Diagram Bentuk Informasi yang Dibutuhkan Pengunjug dalam Berwisata di MMEP Semarang 


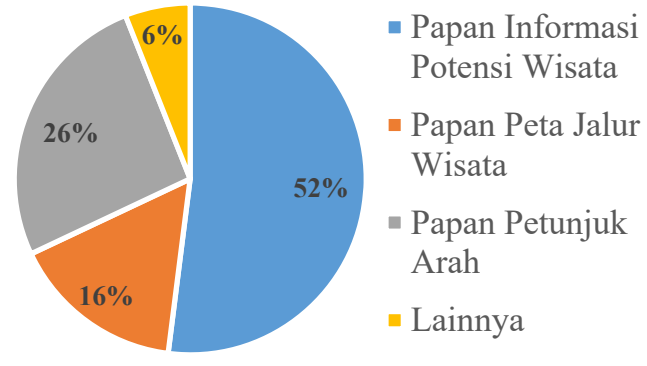

Gambar 12. Diagram Persepsi tentang

Ketersediaan Fasilitas Interpretasi yang Perlu Dikembangkan di MMEP Semarang

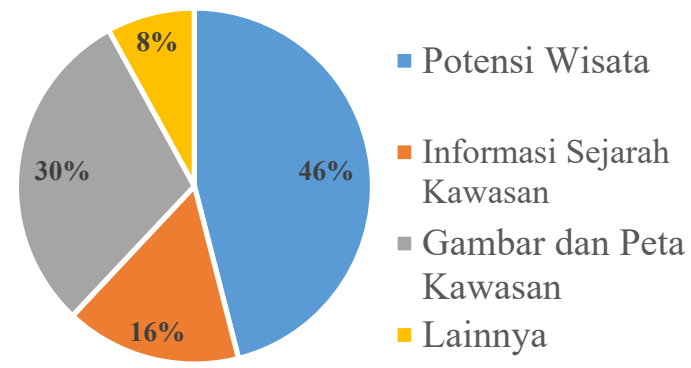

Gambar 13. Diagram Persepsi tentang Konten Fasilitas Interpretasi di MMEP Semarang

Berdasarkan persepsi 50 pengunjung tentang informasi potensi wisata di MMEP Semarang, 70\% mengatakan masih kurang mendapatkan edukasi dan informasi dari fasilitas interpretasi yang sudah berjalan. Hal ini dapat dikaitkan dari persepsi pengunjung tentang bentuk informasi yang dibutuhkan pengunjung dalam menambah informasi dan hasilnya $44 \%$ lebih membutuhkan selebaran peta jalur wisata dan 28\% membutuhkan jasa pemandu wisata. Sedangkan $18 \%$ pengunjung membutuhkan buku panduan wisata dan $10 \%$ sisanya mengatakan membutuhkan papan informasi, leaflet dan 1 orang merasa tidak membutuhkan apa-apa.

Berdasarkan persepsi 50 pengunjung tentang ketersediaan fasilitas interpretasi yang perlu dikembangkan di MMEP Semarang, 52\% mengatakan perlunya pengembangan papan informasi potensi wisata sedangkan $26 \%$ mengatakan perlunya penambahan papan petunjuk arah. Selain itu, $16 \%$ pengunjung mengatakan perlunya pengembangan papan peta jalur wisata karena papan sebelumnya sudah berubah dari bentuk asli kawasan. Persepsi pengunjung tentang konten fasilitas interpretasi di MMEP Semarang menyatakan bahwa 46\% pengunjung kontennya adakah potensi wisata yang menjelaskan tentang jenis-jenis mangrove dan biota yang berasosiasi didalamnya dan fungsi dan manfaat mangrove secara detail. Sedangkan 30\% pengunjung mengatakan konten dari fasilitas interpretasi adalah gambar dan peta kawasan. Hal ini sesuai dengan persepsi pengunjung mengenai bentuk informasi yang dibutuhkan bahwa kebanyakan lebih memilih selebaran peta jalur wisata atau kawasan. Sedangkan $16 \%$ pengunjung mengatakan konten dari fasilitas interpretasi di MMEP adalah informasi sejarah kawasan dan sisanya 8\% mengatakan perlunya konten mengenai informasi peraturan kunjungan dan informasi mengenai kegiatan yang boleh dan tidak boleh dilakukan selama berwisata di MMEP Semarang

\section{e. Persepsi Nilai Penting Wisata di MMEP Semarang}

Tabel 3. Penilaian Pengunjung terhadap Nilai Penting Wisata di MMEP Semarang

\begin{tabular}{|c|c|c|c|c|c|c|c|c|c|c|c|}
\hline \multirow[t]{2}{*}{ Parameter } & \multicolumn{4}{|c|}{ Skor } & \multicolumn{4}{|c|}{$\begin{array}{c}\text { Skor } x \sum \text { Responden per } \\
\text { Skor }\end{array}$} & \multirow[t]{2}{*}{ Total } & \multicolumn{2}{|c|}{ Penilaian } \\
\hline & 1 & 2 & 3 & 4 & 1 & 2 & 3 & 4 & & $(\%)$ & Kriteria \\
\hline Potensi Wisata & 0 & 0 & 14 & 36 & 0 & 0 & 42 & 144 & 186 & 93 & $\mathrm{~A}$ \\
\hline Aksesibilitas & 4 & 25 & 20 & 1 & 4 & 50 & 60 & 1 & 115 & 57,5 & $\mathrm{C}$ \\
\hline $\begin{array}{l}\text { Kondisi Fisik } \\
\text { Papan Informasi }\end{array}$ & 0 & 4 & 35 & 11 & 0 & 8 & 105 & 44 & 157 & 78,5 & $\mathrm{~B}$ \\
\hline $\begin{array}{l}\text { Konten Papan } \\
\text { Informasi }\end{array}$ & 2 & 8 & 31 & 11 & 2 & 16 & 93 & 44 & 155 & 77,5 & $\mathrm{~B}$ \\
\hline
\end{tabular}

Keterangan :

Nilai Total Maksimum : 200

A (Sangat Baik) = dengan nilai $80-100 \%(160-200)$

$\mathrm{B}$ (Baik) = dengan nilai $65-<80 \%(130-<160)$

$\mathrm{C}$ (Buruk) = dengan nilai $35-<65 \%(70-<130)$

$\mathrm{D}$ (Sangat Buruk) = dengan nilai $<35 \%(<70)$

Hasil analisis menggunakan teknik persentase terhadap empat parameter yang ditanyakan kepada responden, sebagaimana ditampilkan pada tabel 3, menunjukkan hasil bahwa penilaian responden terhadap potensi wisata yang ada di MMEP Semarang tergolong paling tinggi dari parameter yang lain yaitu 93\% yang menunjukkan kriteria A atau sangat baik. Salah satu parameter yang ditanyakan yaitu tentang aksesibilitas menunjukkan hasil persentase yaitu 57,5\% yang menunjukkan hasil yang paling rendah diantara parameter yang lain yaitu menunjukkan kriteria $\mathrm{C}$ atau buruk. Penilaian yang diberikan oleh responden mengenai parameter yang ditanyakan sesuai dengan hasil pengamatan dan wawasan responden yang telah berkeliling di kawasan MMEP Semarang. 


\section{Ketersediaan Media Informasi}

Media informasi merupakan bagian dari interpretasi yang sangat penting dalam menunjang kegiatan wisata. Media informasi berperan aktif dalam memberikan pengetahuan serta wawasan terhadap pengunjung agar kegiatan berwisata dalam berjalan dengan lancar. Media informasi termasuk kedalam bagian fasilitas interpretasi baik dalam bentuk papan interpretasi. Media informasi termasuk dalam sebuah proses interpretasi yang sesuai menurut Sharpe (1982), menyatakan perlunya penyusunan perencanaan interpretasi lingkungan dimaksudkan untuk mengoptimalkan, meminimalkan kesulitan dan memaksimalkan efesiensi dari semua sumberdaya ataupun dana, waktu dan tenaga.

Hasil identifikasi media informasi yang ada di kawasan MMEP baik saat menuju lokasi maupun sudah berada dilokasi yaitu terdiri dari papan petunjuk arah, papan informasi kawasan bebas terbatas, papan sejarah penanaman mangrove, gapura, papan informasi karcis biaya masuk, papan informasi sejarah lokasi, papan informasi potensi flora dan fauna, papan jenis mangrove Rhizopora mucronata dan Avicennia marina.

\section{Perencanaan Program Interpretasi di MMEP}

Perencanaan program interpretasi di MMEP dilakukan dengan mulai dari acara FGD (Focus Discussion Group) oleh seluruh stakeholder yang ikut ambil bagian. Kegiatan FGD dilakukan di lokasi wisata yang dihadiri oleh pihak peneliti dan dosen, pihak pengelola yaitu Kelompok METAL, pihak PT. Phapros Tbk dan Yayasan IKAMAT selaku pembina dan konsultan kelompok METAL. Jumlah peserta yang menghadiri kegiatan FGD berjumlah 15 orang.

Hal yang mendasar yang dibahas dalam FGD adalah menjelaskan kepada pihak pengelola, pembina dan konsultan mengenai hasil penelitian selama 1 bulan terhadap pengunjung di MMEP Semarang tentang persepsi terhadap fasilitas interpretasi yang sudah ada dan apa yang menjadi permintaan (demand) dari pengunjung yang berkaitan dengan fasilitas interpretasi. Hasil penelitian tersebut diatas akan dikembalikan ke pihak pengelola dalam merencanakan program interpretasi lingkungan di MMEP Semarang. Berdasarkan hasil tersebut, ternyata pihak pengelola menjelaskan telah merencanakan program pengembangan dalam bentuk Road Map sejak 2015 selama 5 tahun kedepan dalam upaya mengembangkan MMEP hingga tahun 2020. Hasil penelitian terhadap pengunjung mengenai persepsi tentang informasi pontensi wisata, pihak pengelola menyadari bahwa program interpretasi yang sudah ada belum berjalan dengan maksimal kepada pengunjung sehingga 70\% pengunjung masih merasakan kurang mendapatkan informasi pengetahuan.

Menurut hasil penelitian mengenai persepsi bentuk informasi yang dibutuhkan oleh pengunjung, pihak pengelola lebih tertarik untuk mengembangkan program interpretasi dengan teknik secara langsung (attended service) dengan menyediakan jasa pemandu wisata atau tour guide yang orangnya sendiri berasal dari kelompok METAL. Menurut Dirjen PHPA (1998), kualitas dari pemandu wisata sangat diperlukan untuk menentukan tingkat keberhasilan penyampain interpretasi. Pelayanan interpretasi harus disampaikan dalam sebuah cerita tertentu secara proposional (tidak berlebihan dan bukan asal saja), namun tentang ekosistem atau peninggalan-peninggalan sejarah/budaya (Munstasib dan Rachmawati 2009). Rencana kedepan pihak konsultan yaitu Yayasan IKAMAT akan memberikan pelatihan kepada kelompok METAL yang akan dijadikan pemandu wisata. Pelatihan yang diberikan diharapkan agar pemandu wisata dapat memahami mengenai konsep ekowisata, konsep konservasi dan pemahaman tentang mangrove. Tidak semua kelompok METAL akan menjadi seorang interpreter, namum masyarakat yang memiliki kesediaan untuk berpartisipasi secara aktif mulai tahap perencanaan sampai pelaksanaan program interpretasi tersebut, masyarakat yang berkompeten dan memiliki pengetahuan yang luas tentang kawasan MMEP Semarang.

Hasil penelitian mengenai persepsi tentang ketersediaan fasilitas interpretasi yang perlu dikembangkan, pihak pengelola menjelaskan bahwa untuk penempatan papan petunjuk arah di pintu utama bandara Ahmad Yani tidak diperbolehkan oleh Lanumad Ahmad Yani. Salah satu Road Map yang dibuat pihak pengelola meliputi perbaikan fasilitas interpretasi sesuai dengan konten yang diharapakan pengunjung. Hasil kesepakaan tersebut berupa perencanaan program interpretasi dari pengelola akan dijalankan dan diimplementasi sesuai dengan hasil penelitian yang bertujuan untuk pengembangan wisata mangrove yang dapat memberikan memberikan pesan edukasi kepada pengunjung yang datang ke MMEP Semarang. Berikut adalah Road Map mengenai program pengembangan wisata, baik dalam bentuk program interpretasi dan lain sebagainya.

Tabel 4. Road Map Pengembangan Wisata di MMEP Semarang (2015-2020)

\begin{tabular}{|c|c|c|c|c|c|c|c|c|}
\hline \multirow[t]{2}{*}{ No. } & \multirow{2}{*}{\multicolumn{2}{|c|}{ Program }} & \multicolumn{6}{|c|}{ Tahun Pelaksanaan } \\
\hline & & & 2015 & 2016 & 2017 & 2018 & 2019 & 2020 \\
\hline 1 & $\begin{array}{ll}\text { Pengembangan } & \text { Sumber } \\
\text { Manusia (SDM) } & \end{array}$ & Daya & $\checkmark$ & $\checkmark$ & $\checkmark$ & & & \\
\hline 2 & Penanaman Mangrove & & $\checkmark$ & $\checkmark$ & & & & \\
\hline 3 & Sarana / Prasarana & & & $\checkmark$ & $\checkmark$ & $\checkmark$ & $\checkmark$ & $\checkmark$ \\
\hline 4 & $\begin{array}{l}\text { Penelitian, } \\
\text { Pengabdian }\end{array}$ & dan & $\checkmark$ & $\checkmark$ & $\checkmark$ & $\checkmark$ & $\checkmark$ & $\checkmark$ \\
\hline
\end{tabular}

Keterangan:

1. Program pengembangan sumber daya manusia dilakukan pada tahun 2015 s.d 2017. Program pengembangan SDM difokuskan kepada kelompok METAL selaku pengelola MMEP Semarang. Program yang telah dilakukan pada tahun 2015 terkait dengan pengembangan SDM adalah pelatihan teknik rehabilitasi mangrove, pembibitan mangrove, penanaman mangrove serta monitoring mangrove. Tahun 2016, program yang terkait dengan pengembangan SDM 
adalah study visit Karimunjawa. Tahun 2017, program pengembangan SDM yang dilakukan adalah pelatihan penguatan kelembagaan kelompok dan pelatihan dan pembinaan menjadi seorang interpreter atau pemandu wisata.

2. Program penanaman mangrove dilakukan pada tahun 2015 s.d 2016. Program ini melibatkan semua kalangan dan kelompok masyarakat ikut menanam mangrove di kawasan MMEP. Program penanaman secara terfokus terlaksana pada tahun 2015 sedangkan pada tahun 2016 adalah program penanaman mangrove dilakukan lebih menarik dan kreatif yaitu lebih menekankan edukasi mangrove melalui kegiatan diskusi, sharing dan penanaman langsung. Pihak pengelola menamakan program ini dengan sebutan Mangrove Time yang dilakukan sekali dalam sebulan.

3. Program pengembangan sarana / prasaran dilakukan mula tahun 2016 s.d 2020. Program pengembangan sarana / prasarana pada tahun 2016 meliputi peta rencana pembangunan MMEP, pembangunan aula dan toilet, pembuatan papan interpretasi serta pembuatan brosur. Program pengembangan sarana / prasarana pada tahun 2017 meliputi pengadaan tong sampah dan MEP Market. Tahun 2018 program yang terkait dengan sarana / prasarana adalah pengadaan perahu, pembangunan gazebo kecil dan meng-upgrade papan interpretasi yang sudah ada pada tahun 2016. Program pengembangan sarana / prasarana di tahun 2019 meliputi perintisan bank sampah, pengembangan parkir dan memperpanjang jalur tracking mangrove sedangkan pada tahun 2020 kegiatan yang akan dilakukan adalah pembangunan gazebo.

4. Program yang terkait dengan penelitian, pendidikan dan pengabdian dilakukan setiap tahun pada kisaran tahun pelaksanaan. Tahun 2015 kegiatan yang dilakukan adalah menganalisa kerapatan mangrove di MMEP dan social mapping. Tahun 2016 kegiatan yang dilakukan adalah pelatihan pembuatan jajanan mangrove dan pengkayaan spesies mangrove di MMEP Semarang. Tahun 2017 kegiatan yang dilakukan adalah pengkayaan spesies mangrove dan penelitian lanjutan. Tahun 2018 kegiatan yang dilakukan adalah pengkayaan spesies mangrove, Bandeng Fest. Tahun 2019 kegiatan yang dilakukan adalah pengkayaan spesies mangrove, seminar nasional mangrove dan pada tahun 2020 kegiatan yang dilakukan adalah pelatihan batik mangrove dan jurnalisme warga.

\section{KESIMPULAN}

\section{Kesimpulan}

1. Profil pengunjung umumnya adalah pemuda yang berusia 15-24 dan pola kunjungan kebanyakan kolektif / rombongan. Pengunjung kebanyakan berasal dari Semarang Kota dan Kabupaten dan motivasi pengunjung kebanyakan untuk rekreasi. Persepsi pengunjung menyatakan bahwa potensi ekologi yang ada di MMEP Semarang sudah bagus namun masih kurang memberi edukasi lewat program-program interpretasi yang sudah ada.

2. Ketersediaan media informasi sebagai bentuk dari fasilitas interpretasi yang sudah berjalan di MMEP Semarang terdiri papan interpretasi potensi flora dan fauna, papan petunjuk arah, papan informasi biaya karcis, papan sejarah lokasi dan penanaman mangrove serta papan larangan didaerah Lanumad Ahmad Yani.

3. Program interpretasi lingkungan yang akan dikembangkan di MMEP Semarang adalah menyediakan jasa pemandu wisata atau tour guide yang berkompeten dan meng-upgrade fasilitas interpretasi yang sudah berjalan yang sudah tercantum dalam road map pengembangan wisata di MMEP Semarang dari tahun 2015-2020.

\section{Ucapan Terimakasih}

Penulis mengucapkan terimakasih kepada Dr. Ir. Bambang Sulardiono, M.Si atas bimbingan dan arahannya dalam penyusunan jurnal ini.

\section{DAFTAR PUSTAKA}

Arisandi, MH., S. Surbakti dan Nurhasanah. 2014. Eksternalitas Penambangan Pasir Pantai Secara Tradisional terhadap Ekosistem Mangrove dan Sosial Ekonomi Masyarakat Pesisir di Kabupaten Merauke. Jurnal Manajemen Perikanan dan Kelautan Vol. 1 No. 1, 2014 artikel 10. Program Pascasarjana Universitas Terbuka Jakarta.

Athman J, Monroe M. 2004. The Effects Environment Based Education on Students Achievement Motivation. Journal of Interpretation. 9(1):9-25.

Arikunto, S. 2006. Prosedur Penelitian Suatu Pendekatan Praktik. Rineka Cipta. Jakarta.

[Dirjen PHPA]. Direktorat Jenderal PHPA. 1988. Pedoman Interpretasi Taman Nasional. Bogor (ID): Proyek Pengembangan Taman Nasional dan Hutan Wisata.

Indrizal, E. 2014. Diskusi Kelompok Terarah Focus Group Discussion (FGD)-Prinsp-prinsip dan Langkah Pelaksanaan Lapangan. Universitas Andalan. Padang

Muntasib, E.K.S.H. 2003. Perkembangan Interpretasi di Indonesia. dalam Pengembangan Interpretasi Wisata Alam dan Ekowisata. Studio Rekreasi Alam, Departemen Konservasi Sumberdaya Hutan, Fakultas Kehutanan Institut Pertanian Bogor. Bogor.

Muntasib E.K.S.H dan E.Rachmawati. 2009. Rekreasi Alam, Wisata \& Ekowisata. Bogor: Departemen Konservasi Sumberdaya Hutan dan Ekowisata. Fakulta Kehutanan. Institut Pertanian Bogor.

Notoatmodjo, S. 2002. Metodologi Penelitian Kesehatan. Rineka Cipta (Cetakan Kedua). Jakarta. 
Rakhmat, J. 2005. Psikologi Komunikasi. PT. Remaja Rosdakarya. Bandung

Sukandarrumidi. 2006. Metodologi Penelitian : Petunjuk Praktis untuk Peneliti Pemula. Gadjah Mada University Press. Yogyakarta. $201 \mathrm{hlm}$.

Sugiyono. 2009. Metode Penelitian Bisnis (Pendekatan Kuantitatif, Kualitatif, dan R\&D). Alfabeta. Bandung

Skanavis, C., and C, Giannoulis. 2010. Improving quality of ecotourism through advancing education and training of greek eco-tout guides: the role of training in environmental interpretation. Tourismos: An International Multidisciplinary Journal Of Tourism. 5(2):49-68.

Sombowidjojo, R. 1999. Persepsi dan Perlaku Partisipasi dalam Program Penanggulangan Penyakit Deman Berdarah Dengue oleh Masyarakat di Wilayah Puskesmas Magelang Selatan Kotamadya DATI II Magelang.Tesis Program Pasca Sarjana Universitas Gadjah Mada. Yogyakarta.

Sharpe, G. W. 1982. Interpreting the Environment. Outdoor Recreacting College of Forest Resources University of Washington Seattle, Washington. 